[Case Report]

\title{
Two Cases of Familial Primary Pulmonary Hypertension
}

\author{
Kazuhito YAMASHITA, Hiromi TASAKI, Takahiro KuBARA and Yasuhide NAKASHIMA \\ The Second Department of Internal Medicine, School of Medicine, University of Occupational and En- \\ vironmental Health, Japan. Yahatanishi-ku, Kitakyushu 807-8555, Japan
}

Abstract: Case 1, a 28-year-old woman (third daughter of Case 2) delivered her first child in September 2000, but leg edema and dyspnea on exertion appeared the following January. At the time of our first examination of the patient in May 2001, a chest $\mathrm{X}$-ray showed cardiomegaly and pulmonary artery enlargement. Echocardiography demonstrated enlargement of the right ventricle and small left ventricular dimensions, and an electrocardiogram revealed right ventricle hypertrophy. After perfusion-ventilation lung scintigraphy and cardiac catheterization, she was diagnosed as having primary pulmonary hypertension $(\mathrm{PPH})$. Although she was discharged with prescriptions for a diuretic, warfarin and beraprost sodium, she died of a pulmonary hypertensive crisis twenty days after readmission. Case 2, a 60year-old woman (mother of Case 1) developed the same symptoms as those in Case 1, in May 2001, but recovered after medication. PPH is a rare disease and only a few familial cases are reported. In this family, the eldest daughter of Case 2 had also died of pulmonary hypertension ten years ago, several months after her first delivery. In contrast to the daughters, the mother's symptoms developed gradually.

Key words: primary pulmonary hypertension, familial primary pulmonary hypertension, beraprost sodium.

(Received 5 August 2004, accepted 13 October 2004 )

\section{Introduction}

Primary pulmonary hypertension $(\mathrm{PPH})$ is a rare disease, occurring with the incidence of 2 $\sim 3 / 100,000$ and is associated with poor prognosis. Familial PPH(FPPH) accounts for at least $6 \%$ of PPH cases. Here we report two cases of FPPH from the same family. A young woman died two months after her diagnosis of PPH, and her mother is being cared for as an outpatient. The eldest daughter of Case 2 also died of pulmonary hypertension ten years ago, in a manner similar to the third daughter. 


\section{Case Report}

Case 1

A healthy 28-year-old woman gave birth to her first child on September 9, 2000. In January 2001 she consulted a primary physician with complaints of shortness of breath, leg edema, general fatigue and abdominal fullness. Since a blood test indicated low albuminemia, and cardiomegaly was recognized on a chest X-ray, she was admitted to our hospital for further examinations and medical treatment on May 9, 2001.

On admission, her blood pressure was $102 / 64 \mathrm{mmHg}$, and jugular venous distension was present. Cardiac auscultation revealed a loud pulmonic S2 and grade 3/6 systolic murmur over the left upper sternal border. The abdomen was distended and leg edema was present. Immunological test for antinuclear antibodies, anti-DNA antibodies, and anti-cardiolipin antibodies were negative. Factors for coagulation and fibrinolysis were all within the normal range. In arterial blood gas analysis, $\mathrm{PaO}_{2}$ was $56 \mathrm{mmHg}$ and $\mathrm{SaO}_{2}$ was $91.0 \%$. A perfusionventilation lung scintigraphy showed a normal perfusion and ventilation pattern in both lungs. Abdominal echography showed hepatomegaly, ascites and no splenomegaly. Hemodynamic data in the right cardiac catheterization inspection are shown in Table 1. Cardiomegaly, enlargement of the main pulmonary artery, and right pleural effusion were seen on the chest X-ray (Fig. 1A). Echocardiograms (Fig. 1B) showed a dilated right ventricle with small left ventricular dimensions and tricuspid regurgitation in which systolic pulmonary artery pressure was estimated as $90 \mathrm{mmHg}$ by measuring tricuspid pressure gradient. The 12-leads

Table 1. Right cardiac catheterization

\begin{tabular}{lrc}
\hline & Case 1 & Case 2 \\
\hline $\mathrm{mPCWP}(\mathrm{mmHg})$ & 10 & 7 \\
$\mathrm{mPAP}(\mathrm{mmHg})$ & 59 & 45 \\
$\mathrm{RVP}(\mathrm{mmHg})$ & $80 / 8$ & $80 / 4$ \\
$\mathrm{mRAP}(\mathrm{mmHg})$ & 17 & 4 \\
C.O. $(\ell / \mathrm{min})$ & 2.79 & 2.05 \\
C.I. $\left(\ell / \mathrm{min} / \mathrm{m}^{2}\right)$ & 1.86 & 1.60 \\
PVR $\left(\right.$ dynes $\cdot \mathrm{sec}^{\left.-\mathrm{cm}^{-5}\right)}$ & 1428 & 1483 \\
\hline
\end{tabular}

mPCWP: mean pulmonary capillary wedge pressure, mPAP: mean right atrium pressure, RVP: right ventricle pressure, mRAP: mean right atrial pressure, C.O.: cardiac output, C.I.: cardiac index (calculated Fick), PVR: pulmonary vascular resistance 


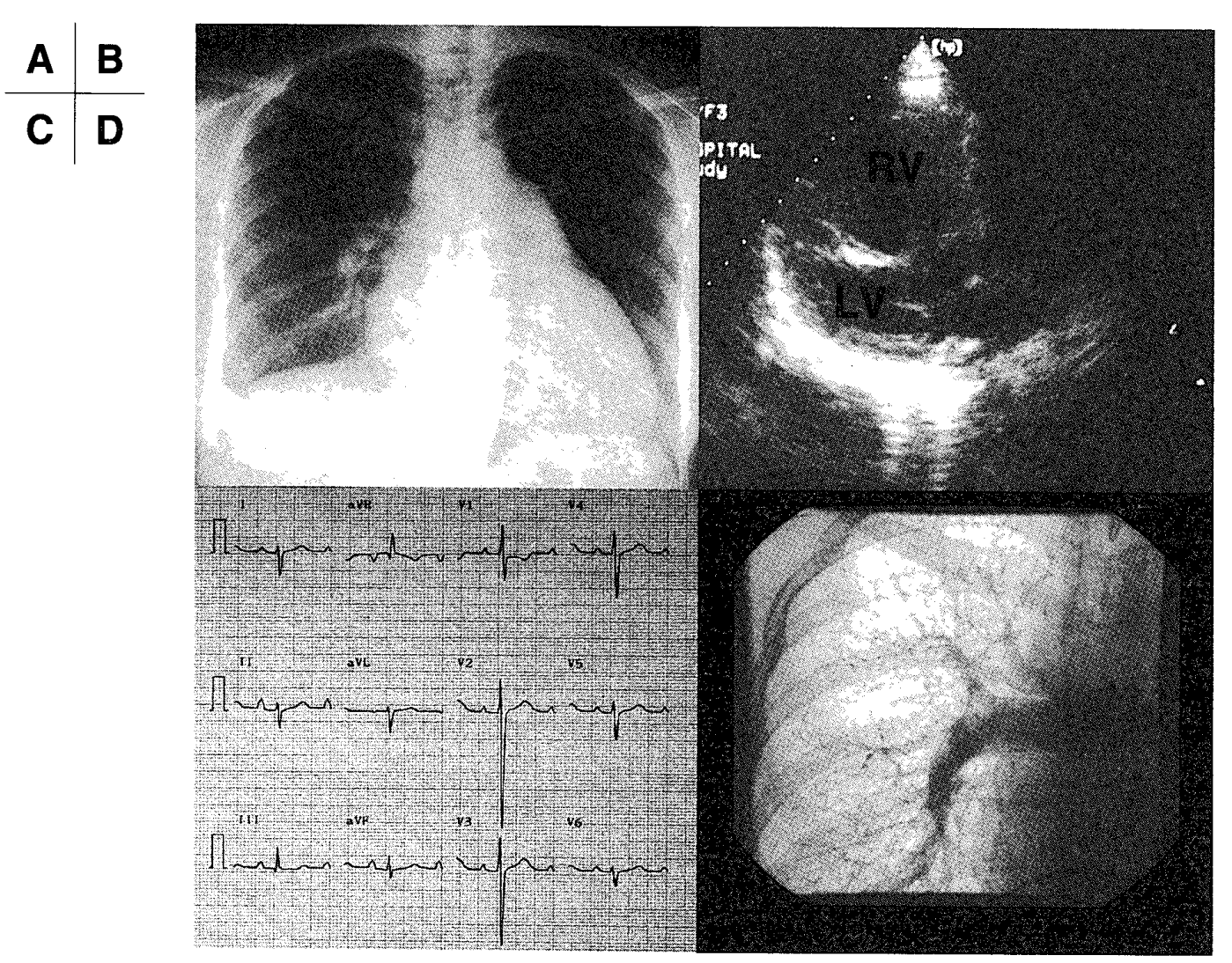

Fig. 1. Chest X-ray (A), echocardiogram $(B)$, 12-leads ECG $(C)$ and pulmonary angiogram (D) in Case 1. RV indicates right ventricle; LV, left ventricle.

ECG revealed right ventricle hypertrophy (Fig. 1C).

At the time of hospitalization, the patient was diagnosed with right heart failure. We considered diseases that cause pulmonary hypertension such as congenital heart diseases or pulmonary artery thromboembolism. Lung ventilation-perfusion scintigraphy was normal and pulmonary artery resistance was markedly elevated in the cardiac catheterization, but we did not recognize any congenital heart diseases. Although dilatation of the main truncus of the pulmonary artery and narrowing of the peripheral pulmonary artery were seen, pulmonary angiography (Fig. 1D) showed no macro-thromboembolism. The patient was therefore diagnosed as having PPH. The patient's pulmonary hypertension was considered to develop after delivery of her child, because 12-leads ECG did not show any right ventricular hypertrophy and right atrial hypertrophy just before delivery (Fig. 2). After a definite diagnosis, administration of warfarin and beraprost sodium(BPS) was started. Her brain natriuretic peptide (BNP) and uric acid(UA) levels were $630 \mathrm{pg} / \mathrm{ml}$ and $8.1 \mathrm{mg} / \mathrm{dl}$, respectively, and the walking distance in 6 minutes was $190 \mathrm{~m}$ after medical treatment. She was discharged on June 19.

Two weeks after leaving the hospital, the patient experienced a reduction of urine volume, 

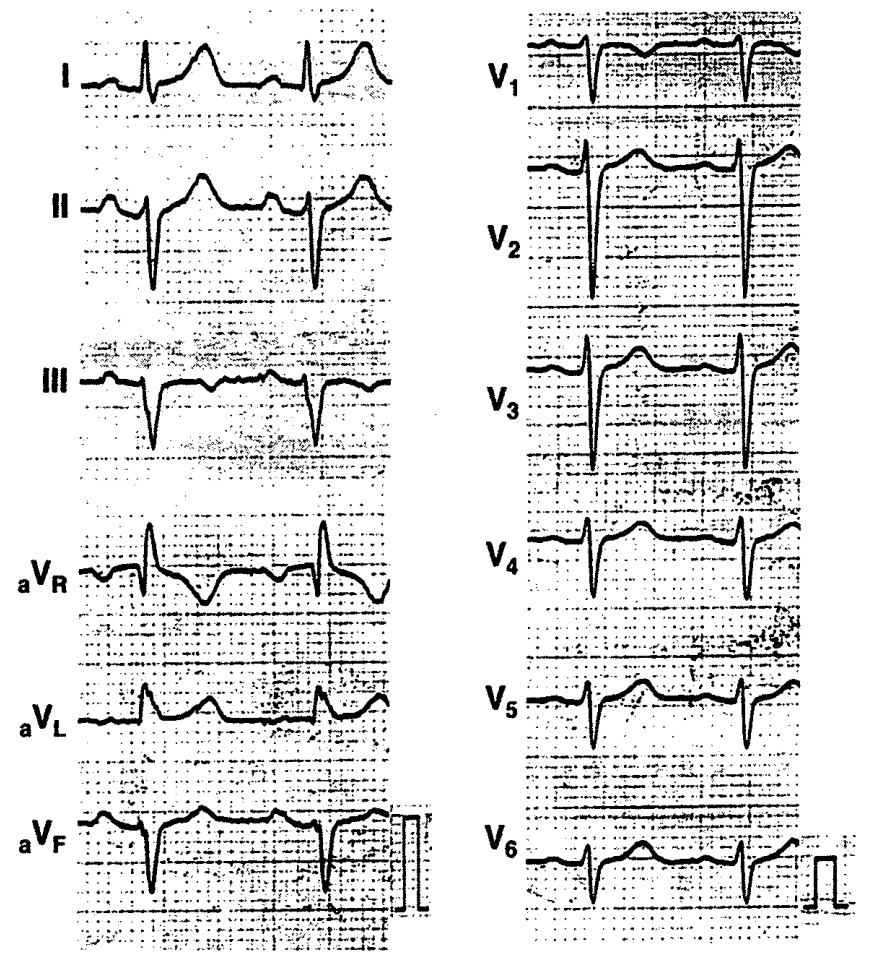

Fig. 2. Case 1, 12-leads ECG before delivery (2000.8.30). ECG shows left axis deviation and clockwise rotation.

\section{\begin{tabular}{l|l} 
A & B \\
\hline C & D
\end{tabular}}

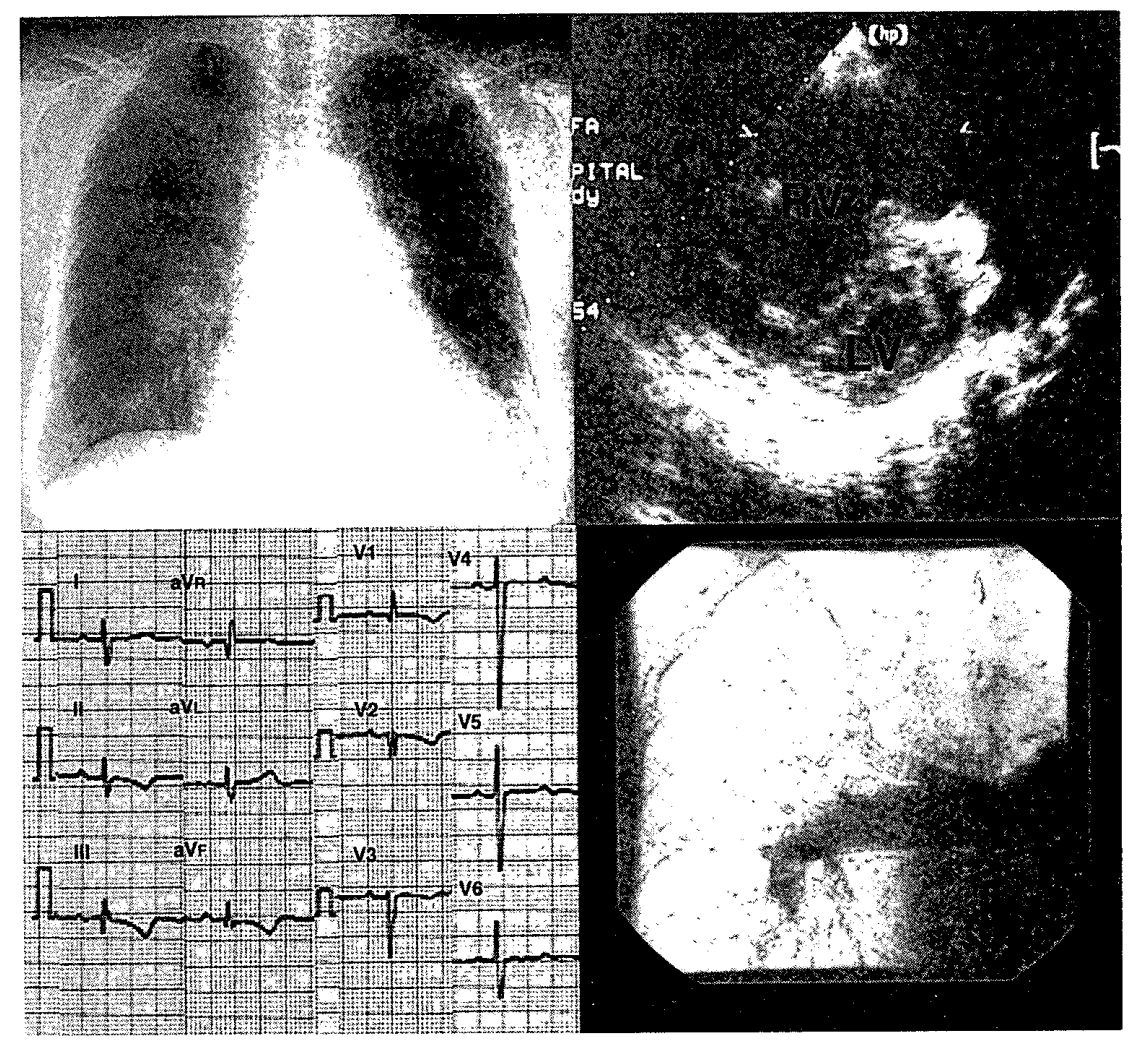

Fig. 3. Chest $\mathrm{X}$-ray $(\mathrm{A})$, echocardiogram $(\mathrm{B}), 12$-leads $\mathrm{ECG}(\mathrm{C})$ and pulmonary angiogram (D) in Case 2. RV indicates right ventricle; $L V$, left ventricle. 
abdominal distention, appetite loss, severe cough and leg edema. Since her condition did not improve even after increasing diuretics, she was re-hospitalized on July 9. On the morning of July 25 , she complained of general fatigue and her blood pressure had fallen. Continuous blood filtration dialysis was started due to advanced metabolic acidosis. However, blood pressure and heart rate suddenly dropped immediately after the procedure, and she died on July 27.

\section{Case 2}

A 60-year-old woman complained of anasarca. She became aware of leg edema at the end of May 2001 and edema of the upper limbs and face appeared in June. Pulmonary hypertension was suspected, and she was admitted to our hospital on June 27.

At the time of hospitalization, her weight was $52 \mathrm{~kg}$ and her blood pressure was 120/90 mmHg. Cardiac auscultation revealed a loud pulmonic $\mathrm{S} 2$ and grade 3/6 systolic murmur over the left upper sternal border. The abdomen was distended and edema was observed in both legs. The chest X-ray, the echocardiography and the ECG(Fig. 3A, 3B and 3C) had almost the same appearance as those in Case 1. In the peripheral blood analysis, polycythemia and liver dysfunction were present. The blood gas measurements revealed the following: pH 7.453, $\mathrm{PaO}_{2} 60 \mathrm{mmHg}, \mathrm{PaCO}_{2} 33.6 \mathrm{mmHg}, \mathrm{HCO}_{3}^{-} 23.8 \mathrm{mEq} / \ell$, and $\mathrm{SaO}_{2} 92.2 \%$.

Pulmonary function tests were normal, and lung ventilation perfusion scintigraphy also had almost normal appearance. Since anasarca was recognized at the time of hospitalization, a diuretic was prescribed and her weight decreased to $42 \mathrm{~kg}$. From the family history, PPH was strongly suspected and medication of warfarin and BPS was started. In a right cardiac catheter inspection performed on August 16, the pulmonary artery pressure was 78/24 $\mathrm{mmHg}$ (a mean of $45 \mathrm{mmHg}$ ). Hemodynamic data on cardiac catheterization is shown in Table 1. Pulmonary angiography (Fig. 3D) showed no thrombus. At this time she was diagnosed as having PPH. Home oxygen treatment was introduced and she left the hospital on September 25. At that time, her BNP and UA levels were $167 \mathrm{pg} / \mathrm{ml}$ and $4.3 \mathrm{mg} / \mathrm{dl}$, respectively, and the walking distance in 6 minutes was $240 \mathrm{~m}$ just before discharge. She is now being treated as an outpatient.

\section{Discussion}

We encountered two cases of FPPH, a mother and her third daughter. The eldest daughter may also have had FPPH since she developed a respiratory condition worsening after delivering a child, and died of pulmonary hypertension. However, because she died about ten years ago, it is unclear whether she definitely suffered from PPH.

As was true for Case 1, PPH is often discovered in women of child-bearing age during pregnancy and delivery. Weiss and others $[1]$ reviewed published reports to evaluate the outcome of pregnancy and delivery in women with pulmonary vascular disease, and reported 
that about $30 \%$ of 27 women with PPH died less than 1 month after giving birth. The physiological changes that occur in pregnancy and delivery can potentially activate the disease and result in death of the mother and/or the child. Even in a healthy person, pregnancy increases in cardiac output from 30 to $50 \%$, in blood volume from 40 to $50 \%$, and in oxygen consumption $20 \%$. Delivery then brings a change in the pulmonary blood vessel tone due to the reduction of blood volume, a low oxygen state, increase of catecholamine, or microthromboembolism, resulting in worsening of the pulmonary vascular disease [2].

PPH is defined as a progressive, intractable and often-fatal disease of unknown etiology. The small precapillary pulmonary arterioles in patients with PPH are characterized by medial hypertrophy, concentric laminar intimal fibrosis, plexiform lesions with obstruction of the arterial lumen, and proliferation of inter-connected channels $[3,4]$. PPH occurs with a frequency of $2-3$ persons $/ 1$ million people, a male to female ratio of $1: 2$, and a mean age at onset of 36 years old. FPPH is estimated to represent approximately $6 \%$ of all cases of PPH. Deng has reported the mutations in Bone Morphogenetic Protein Receptor-II (BMPR-II) gene on chromosome 2q31-32 in some cases of FPPH [5]. BMPR-II is a member of transforming growth factor-beta(TGF-beta) receptor, and mutant of BMPR-II, in which the 354th thiamine is replaced with guanine, may not inhibit the proliferation of smooth muscle cells in the pulmonary artery [6]. However, those who present PPH clinically in a career with the BMPR-II gene mutation are only $10-20 \%$ in FPPH. Other environmental factors, estrogen, or other gene mutations that are not known yet may participate in pulmonary hypertension $[6$, 7 , and may explain why the clinical development was quite different between Case 1 or the eldest daughter of Case 2 and Case 2.

D'Alonzo and others reported that the one-, three- and five-year survival rate of PPH was 68,48 and $34 \%$, respectively, and that the prognosis was strongly influenced by the right heart function, measured by average right atrium pressure, average pulmonary artery pressure and the cardiac output index $[8]$. According to this report, one- and three-year survival rate of Case 1 was 55.5 and 29.4\%, and that of Case 2 was 74.7 and $54.5 \%$. On the other hand, Nagaya et al . recently reported that UA, BNP and the 6 minutes walk test are important factors for specifying a prognosis. Values of BNP over $180 \mathrm{pg} / \mathrm{ml}$, values of UA over 8.9 $\mathrm{mg} / \mathrm{dl}$ for a man or $6.4 \mathrm{mg} / \mathrm{dl}$ for a woman, and a distance walked in 6 minutes of less than $322 \mathrm{~m}$ suggest a poor prognosis $[9-11]$. According to these criteria, a poor prognosis also would have been expected for Case 1, but not for Case 2. Furthermore, in comparatively mild cases of PPH, the prognosis has been improved after administering BPS, an orally active prostacyclin analogue that strongly dilates blood vessels and inhibits platelet aggregation [10]. The oral prostacyclin we used for Case 2 has few side effects or complications as compared to continuous intravenous infusion of $\mathrm{PGI}_{2}$. In a worsening case where internal medical treatment is not successful and the patient continues to worsen, it is necessary to take into consideration a lung transplantation or a heart and lungs simultaneous transplantation.

Although the method of detecting the BMPR-II gene mutation has not been clinically estab- 
lished yet, it may soon be possible to perform a gene diagnosis of the patient with a high risk of FPPH. In a patient with the genetic mutation, but no symptoms, it may become possible to diagnose the pulmonary hypertension at an early stage using Doppler echocardiography, and we may also be able to perform early detection and early treatment in the near future.

\section{References}

1. Weiss BM, Zemp L, Seifert B \& Hess OM(1998): Outcome of pulmonary vascular disease in pregnancy: a systematic overview from 1978 through 1996. J Am Coll Cardiol 31: 1650-1657

2. Stewart R, Tuazon D, Olson G \& Duarte AG(2001): Pregnancy and primary pulmonary hypertension : successful outcome with epoprostenol therapy. Chest 119: 973-975

3. Barst RJ (1999): Recent advances in the treatment of pediatric pulmonary artery hypertension. Pediatr Clin North Am 46: $331-345$

4. Gaine SP \& Rubin LJ(1998): Primary pulmonary hypertension. Lancet 352: 719-725

5. Deng Z, Morse JH, Slager SL et al (2000): Familial primary pulmonary hypertension (gene PPH1) is caused by mutations in the bone morphogenetic protein receptor-II gene. Am J Hum Genet 67: $737-744$

6. Loscalzo J(2001): Genetic clues to the cause of primary pulmonary hypertension. N Engl J Med 345: $367-371$

7. Newman JH, Wheeler L, Lane KB, Loyd E, Gaddipati R, Phillips JA 3rd \& Loyd JE (2001): Mutation in the gene for bone morphogenetic protein receptor II as a cause of primary pulmonary hypertension in a large kindred. $\mathrm{N}$ Engl J Med 345: $319-324$

8. D’Alonzo GE, Barst RJ, Ayres SM et al (1991): Survival in patients with primary pulmonary hypertension. Results from a national prospective registry. Ann Intern Med 115: 343-349

9. Miyamoto S, Nagaya N, Satoh T, Kyotani S, Sakamaki F, Fujita M, Nakanishi N \& Miyatake K (2000): Clinical correlates and prognostic significance of six-minute walk test in patients with primary pulmonary hypertension. Comparison with cardiopulmonary exercise testing. Am J Respir Crit Care Med 161: 487-492

10. Nagaya N, Uematsu M, Okano Y, Satoh T, Kyotani S, Sakamaki F, Nakanishi N, Miyatake K \& Kunieda T(1999): Effect of orally active prostacyclin analogue on survival of outpatients with primary pulmonary hypertension. J Am Coll Cardiol 34: 1188-1192

11. Nagaya N, Uematsu M, Satoh T, Kyotani S, Sakamaki F, Nakanishi N, Yamagishi M, Kunieda T \& Miyatake K(1999): Serum uric acid levels correlate with the severity and the mortality of primary pulmonary hypertension. Am J Respir Crit Care Med 160: 487-492 
家族性原発性肺動脈高血圧症の二症例

山下 和仁, 太崎 博美, 久原 孝博, 中島 康秀

産業医科大学 医学部 第二内科学教室

要 旨： 症例一(症例二の三女, 28歳)は, 平成12年 9 月長男を出産, 翌年 1 月より下肢の浮腫, 労作時の呼吸苦が出現.平成13年 5 月初診時, 心拡大·肺うっ血が認められ,心電図上 右室負荷, 心エコーにて, 右室の拡大,左室の圧排を認めた.肺換気血流シンチグラフ イーおよび心臓カテーテル検査の結果, 原発性肺高血圧症 $(\mathrm{PPH})$ と診断された.利尿剂 などの投与により,改善を認め退院となったが, 1 カ月後肺高血圧 crisisのため死亡し た. 症例二(症例一の母, 60 歳)は, 平成13年 5 月より, 症状が出現, 症例一と同様の所見 を認め,内服加療により症状軽快し経過観察中である.PPH は稀な疾患であり家族性 の報告も少ない. 長女の場合も症例一と同様に, 第一子出産後, 肺高血圧症のため死亡 した. 症例二は，緩徐な経過で発症したと考えられる.今回我々は, 家族性原発性肺高 血圧症の二症例を経験したので報告する。

キーワード： 家族性原発性肺高血圧症, 肺高血圧症, ベラプロスト.

J UOEH（産業医大誌）26（4)：443-450（2004） 